\title{
THE ROLE OF PARENTS IN FORMING SPIRITUAL EDUCATION ON THE BASIS OF CREATIVE APPROACHES
}

\section{Islamova F.Sh.}

Senior Lecturer, National Institute of Art and Design named after Kamoliddin Behzod, Uzbekistan

Vaniyan S.B.

Senior Lecturer, National Institute of Art and Design named after Kamoliddin Behzod, Uzbekistan

\section{ABSTRACT}

This article is devoted to one of the most pressing problems of family pedagogy - the role of parents in the formation of spiritual education in the family on the basis of creative approaches. The article clearly shows the issues of raising the level of spirituality on the basis of parental love and affection for the upbringing of children in the family, special attention and creative approaches in the educational process, considering the requirements of family upbringing and ways to organize it properly.

KEYWORDS: - Upbringing, creative approach, upbringing of children in the family, spiritual and moral upbringing, national traditions, customs, values.

\section{INTRODUCTION}

It is known that in our country special attention is paid to the education of the younger generation. A number of measures are being taken to create the necessary conditions for boys and girls to receive modern education and grow up with high spirituality.

The relationship between the Uzbek family and family members has its own national characteristics, and the spiritual values inherited from the older generations are based on the spiritual upbringing of the family, which is based on traditions. In the words of our President Sh.
Mirziyoyev: "Another important issue that always worries us is the morals, behavior, in a word, the worldview of our youth. Today the times are changing rapidly. Young people are the ones who feel these changes the most. May the youth meet the requirements of their time. But at the same time, let him not forget his own. May the call of who we are and what a generation of great beings always resonate in their hearts and motivate them to remain true to themselves. How do we achieve this? Upbringing, upbringing and only at the expense of upbringing". [1]

\section{Methods}


CURRENT RESEARCH JOURNAL OF PEDAGOGICS 2(12): 162-165,

December 2021 DOI: https://doi.org/10.37547/pedagogics-crjp-02-12-32

ISSN 2767-3278

(C)2021 Master Journals

Crossref do: 81 Google

Accepted 25 th December, 2021 \& Published 30 th December, 2021

The role of education and upbringing, family and older generation in the formation of the younger generation as a harmonious and mature person is invaluable. The sages liken the child to a young plant. When a crooked plant becomes a crooked tree, the command to correct it becomes an impossible task. If a child is not brought up in the family and society as a pamphlet from an early age, it will be difficult to guide him in the right direction as he grows up. For this reason, the famous Eastern thinker, our great ancestor Abu Ali Ibn Sino, in his book "Encyclopedia" emphasizes that the responsibility of parents is primarily for the upbringing of children. A great scholar also thinks about the upbringing of children and pointed out about the huge influence of the environment: "Where a young child is educated, there should be children who are well-mannered and well-behaved. After all, a young child learns everything by imitating them and becomes friends with them".

The influence of the family environment on the mental and physical health of children in the family is great, because children grow up under the same environment as the family environment. The family environment, along with the impact on the children, adapts them to the life around them. In society, raising children to be mentally and physically healthy is not only a personal but also a social duty of parents. Therefore, it is important for every parent to decide on a healthy lifestyle in the family, to achieve its socio-economic stability and wellbeing, to bring up an educated, intelligent, resourceful, intelligent, spiritually and spiritually mature person, such as the family traditions, professions, ensuring the continuity of the family tree, achieving productive leisure time for a child, drug addiction, domestic uncleanness, immorality, unhealthy beliefs, bigotry, treason preventing the appearance of certain defects, such as doubling the sense of responsibility for duties and responsibilities.
In our mentality, children try to be like their parents, and parents unknowingly instill in their children their own character and traits. Kindness, which is one of the characteristics of such a character, is passed from parents to children. Kindness, constant supervision, and friendly advice are especially important to children in their teens today when a parent takes a creative approach to their child. But sadly, many parents are afraid of this wonderful human feeling in order not to make their child "unruly". They worry that the child will become sophisticated, selfish. But many negative traits occur in situations where the child is deprived of the proper kindness, caress, attention of the parents. That is why it is an important task of a parent to make sure that the child loves and takes care of himself.

For any child, first and foremost, the love and affection shown by the parents is necessary. In the majority of street children who are involved in crime, the kindness and attention not shown by their parents in time will cause them to be on this path. It is not uncommon for children growing up in such an unhealthy family environment to be mentally depressed and to have various problems in their lives. In addition, as a result of idleness, alcoholism, theft, drug addiction, crime can take to the streets or fall under the influence of various criminal and religious extremist groups. In the family, it is the siblings, and later the parents, who find out what the teenager is constantly doing and what he or she is doing. But a great responsibility, such as raising a family, falls first and foremost on the father and mother.

Attention to the younger generation in our country is one of the most important issues facing society and the state. Our Constitution has a separate chapter on the family. Article 64 of the Family Chapter states, "Parents are obliged to support and educate their children until they reach adulthood. The state and society provide 
CURRENT RESEARCH JOURNAL OF PEDAGOGICS 2(12): 162-165,

December 2021 DOI: https://doi.org/10.37547/pedagogics-crjp-02-12-32

ISSN 2767-3278

(C)2021 Master Journals

Crossref doi) 81 Google

Accepted 25th December, 2021 \& Published 30 th December, 2021

for the upbringing and education of orphans and children deprived of parental care, and encourage charitable activities for children".

It should be noted that such a high attention to the younger generation is associated with our historical values, traditions and customs. If we look at the recent history, hundreds of thousands of children who were left homeless during the Second World War, separated from their parents and relatives, found their homeland in the heart of Uzbekistan, their homes in Uzbek homes. Despite the difficult conditions, Uzbek families have brought up children of different nationalities.

At the same time, in the context of growing conflicts in many countries around the world, time itself shows that it is more important than ever to strengthen the spiritual immunity of our children, to spend their free time meaningfully.

In the formation of a spiritual upbringing in the family environment, which lays a solid foundation on the basis of creative approaches, parents should not neglect the following tasks:

- increase interest in music, painting, literature, theater and other arts in order to enrich the aesthetic outlook of the family;

- physical training in the formation of a healthy lifestyle, creating the necessary conditions in the family for them to demonstrate their abilities in sports;

- peace of mind in the family, sincere attitude, high prestige of parents;

- maintaining unity among family adults in making demands on children;

- pay special attention to the education of the child's personality in labor;

- $\quad$ to love and honor the child;

- establishing a strict regime and agenda in the family;
- taking into account the age and personal characteristics of the child;

- tracking changes in the child, striving for independence in him or her and supporting the qualities of initiative;

- to enrich the bookshelf in order to increase the enthusiasm for reading in a family environment.

\section{Conclusion}

In conclusion, the parental and family environment is of great importance for the upbringing of a generation in the family with strong spiritual immunity, the ability to express themselves fluently, to achieve high goals. It is no secret that at a time when the increasing of the various dangers such as occupying the human heart and mind, especially those aimed at poisoning the spiritual world of the youth, only a young generation with a deep understanding of who they are, what an invaluable heir they are, living with love and devotion to the motherland, strong faith will be able to protect our sacred land from foreign influences and disasters, to develop our Motherland in all respects.

\section{REFERENCES}

1. Shavkat Mirziyoyev on the education of the younger generation in his speech at the conference "Ensuring social stability, preserving true essence and content of Islamic religion - the need of the time" 2017 y. June 15.

2. Abu Ali Ibn Sino. "Donishnoma" ("Encyclopedia").

3. Исламова Ф.Ш. Миллий анъаналар асосида ўғил болаларни оилага тайёрлашнинг педагогик-психологик усуллари. "Таълим, фан ва инновация". Маънавий-маърифий илмий-услубий журнал. Тошкент. 2019/3-сон. (Islamova 
CURRENT RESEARCH JOURNAL OF PEDAGOGICS 2(12): 162-165,

December 2021 DOI: https://doi.org/10.37547/pedagogics-crjp-02-12-32

ISSN 2767-3278

(C)2021 Master Journals

Crossref dof 81 Google

Accepted 25th December, 2021 \& Published 30 th December, 2021

F.Sh. Pedagogical and psychological methods of preparing boys for marriage on the basis of national traditions. "Education, Science and Innovation". Spiritual-enlightenment scientificmethodical journal, Tashkent, 2019/3).

4. Rakhmanova F.Sh. Pedagogical views of interstitial thinkers in preparing boys for family life based on national traditions. Young Scientist "No. 4. Founder and publisher: Perm Publishing House. 39) / 2012

5. F.Sh.Islamova, F.Sh.Fayazova. Family traditions in vocational guidance, a guarantee of preparing young people for independent living. ACADEMICIA An International Multidisciplinary Research Journal (Double Blind Refereed \& Peer Reviewed Journal). ISSN: 2249-7137 Vol. 11, Issue 10, October 2021. 